\title{
MASCULINITY, MEMORY, \\ AND OBLIVION IN THE DUTCH \\ DOMINICAN PROVINCE, 1930-1950
}

\author{
MARIT MONTEIRO
}

Unfortunately I lost your last letter; it was probably torn up by the brother responsible for the cleaning. I do know, however, that your words (mostly of complaint) made me think: why is he always thinking about what he should become, and not so much about what he actually is; why doesn't the priesthood suffice us? At the age of 24 we have become what we are supposed to be, our duties have been carefully mapped out for us, as is our entire life, and we are equipped to live up to what we should be. You know exactly to what you should dedicate your strength, a certainty that precludes the hesitation that is common amongst other youngsters, a hesitation that diminishes the productiveness of so many lives. We are so used to saying that besides a priestly ideal we also have a Dominican ideal, which, as we point out, prevents us from reconciling ourselves with the clerical existence of a chaplain (!) for example. Yet, I am pretty sure that this is definitely the wrong way of looking at things. ${ }^{1}$

7 his is what the Dominican Pius de Winter (1914-1944) wrote to his fellow brother Lucas Grollenberg (1916-1997) in December 1943, in the thick of the Second World War. De Winter had been stationed in Teutonia, the Dominicans' German province, since 1941, more specifically the Thomas Convent in Venlo, a town just over the German border in north of the county of Limburg. Here, he was supposed to become more proficient in the German language that he was meant to teach at Saint Dominic's College, the minor seminary of the Dutch province, located in Neerbosch, a village in the vicinity of Nijmegen. Grollenberg lived in the Thomas Convent in

'Sint Agatha, Erfgoedcentrum Nederlands Kloosterleven, Provincial Archives of the Dutch Province of the Order of the Dominicans (hereafter PAOD), 8359a: Pius de Winter to Lucas Grollenberg, Nijmegen, 2 December 1943. 
Zwolle, approximately 160 kilometres from Venlo. Ten of de Winter's letters survived the war and are kept in the archives of the Dutch Dominicans. The letters Grollenberg wrote to de Winter were probably lost during the war, when de Winter was killed on 22 February 1944 when Allied Forces mistakenly bombed Nijmegen. ${ }^{2}$

De Winter's letters grant us a glimpse of the conceptions of masculinity in the constructions of identity and collective memory amongst a group of prominent 'priests religious' in the Netherlands. ${ }^{3}$ Both he and Grollenberg were part of a generation of angry young Catholics who brooded over the clericised Catholic culture of the Netherlands. As representatives of this very culture, these young preachers naturally profiled themselves as only moderate malcontents. They did, however, seriously ponder the dominance of the clerical dimension in their Dominican identity. Although the exchanges in their private correspondence were personal, their letters reflect the collectively construed and gendered parameters of that identity. Their discussions of its clerical and monastic dimensions are entwined with notions of masculinity and authority. Lay members of their generation challenged existing patriarchal patterns of authority within the Catholic community with new, essentially virile and vital repertoires of Catholic masculinity, in which evangelical zeal and vigour defied the established clerical control upon which the Dominican self-image as 'men of their times' essentially relied.

Conceptions of masculinity remained part and parcel of the central narrative of Dominican identity. In this chapter I explore these conceptions and their function in the commemorative culture of the Dutch province between the 1930 and the 1950 . By focusing on this particular group of core Catholics, I will show that in the history of nineteenth- and twentieth-century Western Europe 'Christian manliness' has no fixed meaning, but requires a more nuanced analytical differentiation. Recent scholarship is dominated by sweeping theses that posit the masculinisation or re-masculinisation of religion in reaction to what came to be known as the feminisation of religion during the nineteenth century. ${ }^{4}$ Both the narrative of feminisation and the perceived need for a re-masculinisation of religion do in fact tally with the secularisation thesis as an explanation of religious transformation; this thesis contends that religion dominated the women's sphere, particularly among the bourgeoisie. Recently this secularisation thesis has lost ground because it largely neglects the social, cultural, and political forcefulness of religion since 1840 , a period marked by burgeoning modernity. ${ }^{5}$

\footnotetext{
${ }^{2}$ See also Rosendaal, Nijmegen '44.

${ }^{3}$ Monteiro, Gods Predikers.

${ }^{4}$ See Yvonne Maria Werner's introduction to this volume and the chapter by Olaf Blaschke. The term 'feminisation of religion' was used by the French historian Claude Langlois (Le Catholicisme au féminin) in order to describe the increasing number of women attracted to Catholic religious institutes in nineteenth-century France, as well as the feminisation of religious practice, reflected in an intensified Marian devotion since 1854. See also Busch, "Die Feminisierung der ultramontanen Frömmigkeit". American historians have instead focused on the feminisation of Protestantism, relating it to the separation of spheres in bourgeois culture. See in particular Welter, "The feminisation of American Religion" and Smith, Ladies of the Leisure Class.

${ }^{5}$ See Cox, "Secularisation and Other Master Narratives of Religion in Modern Europe"; Id., "Master Narratives of Long-Term Religious Change". See also Brown, The Death of Christian Britain; and McLeod, The Religious Crisis of the 1960s.
} 
The German historian Olaf Blaschke has characterised the century to 1940 as the second era of confessionalisation, in which religion in all its denominational variants, far from being pushed to the margins of society, fostered a variety of essentially gendered processes of confessionalisation to which both women and men were party. ${ }^{6}$

This chapter aims to establish that the processes and patterns of the gendering of religion were invariable subtle, and at times almost undetectable. Moreover, it highlights that Christian manliness as a category applied in a variety of collective identities: lay and clerical, clerical and monastic. ${ }^{7}$ Although the Dutch Dominicans are centre stage, the patterns of masculinity they cultivated in their community can be considered valid for other male religious orders in the Netherlands. ${ }^{8}$ Until well into the twentieth century male religious institutes administered an increasing proportion of the parishes in the Netherlands, and left their mark on confessional Catholic culture.

I have chosen the relatively new field of memory studies as my frame of reference, in particular the work of the German literary theorist Aleida Assmann. Memory studies concentrate on the dynamic and essentially social character of collective memory. Within the context of what is termed 'the new cultural history', 'memory' has acquired the status of a meta-category that serves to explore the boundaries of history. Many theoretical appreciations of memory therefore invest in its specific relation to history, whereas the direct link to current constructions of identity is no less relevant. ${ }^{9}$ For this chapter I concentrate on memory as a narrative structure that channels historical perception into canonised memory through what Assmann has called Erinnerungspraxis. ${ }^{10}$ 'Memory practice' refers to the process of selection and appropriation by which 'history' becomes 'memory' that serves to underpin collective identities. ${ }^{11}$ My exploration starts with an analysis of the re-invention of the Dominican identity in the 1850 as an essentially monastic identity. This re-invention, devised by the master general of the order, imposed a problematic outline on the Dutch Dominicans, who mainly served as parish priests rather than contemplative monks. The tension between being a man of God or a man of the Church, homo Dei or homo Ecclesiae, had to be solved periodically, and collective commemorations proved to be the favoured means. I will illustrate this by focusing on two cases: the celebration of the seventh centenary of the canonisation of the founder of the order in 1934, marked by the appearance of a commemorative volume; and the appear-

${ }^{6}$ Blaschke, “Der Dämon des Konfessionalismus”.

7 See also my article, "Repertoires of Catholic Manliness in the Netherlands".

${ }^{8}$ See for example De Kok, Acht eeuwen Minderbroeders in Nederland.

${ }^{9}$ In this fast-growing field, see in particular Erll, Kollektives Gedächtnis und Erinnerungskulturen;

Erll and Nünning, eds, Cultural Memory Studies; and the critical evaluation by Klein, "On the Emergence of 'Memory' in Historical Discourse". Theoretical discussions in the Netherlands focus on the role of an historical canon, as well as the relation between heritage and history: Grever, "Nationale identiteit en historisch besef"; Jonker, "Wilde herinnering en getemde geschiedenis"; and Frijhoff, Dynamisch erfgoed.

${ }^{10}$ Assmann, Der lange Schatten der Vergangenheit.

${ }^{11}$ Assmann limits herself to this interpretation, whereas the notion of Erinnerungspraxis seems to be equally valid for the practice by which the social or generational memory of eyewitnesses or participants is transformed into (scholarly) history. See Schloesser, "Against Forgetting". 
ance in 1948 of the brochure entitled Wat is een Dominicaan? (What is a Dominican?). Whereas the first had academic ambitions but only a small print run, the second was an illustrated leaflet, printed in a run of 10,00o, intended mainly for the recruitment of pupils for Saint Dominic's College. These publications illustrate how the Dutch Dominicans forged and disseminated a self-image that can aptly be summarised as monastic, masculine, and missionary. In both publications the Preachers actively instrumentalised the past, bringing the monastic and missionary aspects of their order to the fore, while maintaining a tactful silence on the bulk of the Dutch province's parochial responsibilities. On an ideological and mental level they affirmed a heroic monastic masculinity that was both militant and mobile, thereby distancing themselves from what they disdained as a sedentary, even bourgeois clerical manliness associated with the parishes in the Netherlands and in the missions overseas to which they were bound on a practical level.

\section{HOMINES DEI, HOMINES ECCLESIAE?}

Since the revival of their order, to which the Dutch Dominicans made a substantial contribution, they had never doubted their superiority to the diocesan clergy. Secular and regular clerics alike supported the parochial structure of the Dutch Church after the episcopal hierarchy had been restored in 1853. However, the monastic character of the restoration programme of the entire order, forged by its master general Vincent Jandel (1810-1872), put their commitment to the parishes as well as their actual function as parish priests under severe pressure. Jandel's programme prioritised monastic observance and rigorous discipline, interweaving historical repertoires with urgent concerns about present and future legitimacy. His answer to these concerns was to refer to the history of the order and reframe it as tradition. Jandel thus attempted to direct the energy and expectations of his fellow brothers beyond the temporary toward less ephemeral tenets, anchored in the founder and foundation of the order and the first centuries of its existence. It is therefore not surprising that most efforts at historical research in the order were, and are still, concentrated on this initial period, neglecting later and less heroic episodes in its history. ${ }^{12}$

Jandel's project in fact aimed to disconnect social memory from actual experience. Aleida Assmann points out that severing the ties between experience and social memory is a prerequisite for the creation of a shared cultural memory. She characterises social memory as short-term memory, which relies mostly on communication, and is (biologically) limited to a time-horizon of three, perhaps four subsequent generations. Cultural memory, however, has a performative power that transcends time, although it is based on images and symbols derived from history. History is transformed into sustained forms of cultural memory by objectifying these images and symbols into experiences that are thus cut loose from actual historical subjects, and turned into material or immaterial bearers and markers of cultural memory. These bearers or markers can be appropriated and internalised by those who were not eyewitness participants; they can join and stabilise a collective memory by this proc-

${ }^{12}$ Monteiro, Gods Predikers, 29-33, 84-87. 
ess of appropriation, and ground their identity on this memory, which is designed to transcend time. As Assmann aptly puts it, institutions do not possess a collective memory, yet they create it. ${ }^{13}$

This applies neatly to the order of the Dominicans, yet the history of the Dutch Province also allows us to fathom the impact of contesting memories on Jandel's creation of collective memory. His programme of re-monasticisation met with resistance in the Netherlands because of the parochial responsibilities of the Dutch Dominicans. ${ }^{14}$ Although the Dutch Dominicans felt superior to the secular clergy, their communal culture was inherently clerical, and nowhere more so than in the rectories, where they came close to mirroring the way of life of the secular clergy that dated back to the second half of the nineteenth century. It was then that the Dutch Church had changed its outward appearance and inner self-conception from the missionary church it had in truth been since the end of the sixteenth century, partly priest-less and dependent on lay patronage, into a full-blown institutional church under clerical control. ${ }^{15}$ Since the end of the nineteenth century, secular clerics had been more consistently trained to become men of the Church (homines Ecclesiae) rather than men of God (homines $\mathrm{Dei}$ ). The Church came to be defined in terms of ultramontane Catholicism: a manual for priests of 1938 explained that the heart of the clergy should pound for Rome, "for the throne of unity, for the centre of the entire community". ${ }^{16}$ It went without saying that it was the Papal throne that was meant.

This dominant construction of clerical identity had far-reaching consequences for regular clerics such as the Dominicans, whose collective identity since about 1850 had been framed in monastic rather than clerical terms, as we have seen. From the outset, their founder Dominic (1170-1221) had envisaged a fruitful combination of monastic and clerical traits in the way of life of his followers. In the thirteenth century, Thomas Aquinas conceptualised the functional relationship between the active and contemplative elements in Dominican identity, expressed in the order's motto, contemplari et contemplata aliis tradere; to him, contemplation and sharing the fruits of contemplation with others ultimately exemplified religious life. In the daily reality of the Dutch province, the attempt to strike a balance between action and contemplation often proved to be rather trying. As a result of the liturgical and pastoral duties in the parishes for which the Preachers were responsible, action was easily equated with parochial obligations, reinforcing the clerical dimension of Dominican identity. The need for contemplation was emphasised in order to keep a necessary check on action in the busy and time-consuming parishes. Between 1900 and 1920 the Dutch Dominicans attempted to balance the two poles of their identity by distinguishing between identity and function. They considered themselves to be Dominicans and, as such, monastic men, whereas the majority functioned as parish priests. ${ }^{17}$

Continuous attempts to balance action and contemplation, the clerical and monastic attributes respectively, nearly succumbed in the 1930 s to the pressure of

\footnotetext{
${ }^{13}$ Assmann, Der lange Schatten der Vergangenheit, 29-36.

${ }^{14}$ Monteiro, Gods Predikers, 75-89.

${ }^{15}$ Id., "Mannen Gods", 16-18.

${ }^{16}$ Stockums, Priesterschap en ascese, 253.

${ }^{17}$ Monteiro, Gods Predikers, 184-196.
} 
two, interrelated developments. The often far-reaching authority of the clergy within the Dutch Catholic community had been under open attack since the mid 1920 from a new generation of young, academically trained Catholic laymen who saw their hopes of significant professional positions in part thwarted by the clergy. They scorned the clerical monopoly on areas not directly related to the Church, and claimed recognition as Catholic professionals. In a broader perspective, their criticism echoed the consequences of the process of confessionalisation that in the Netherlands had amounted to pillarisation: a largely autarkic denominational subculture dominated by Catholic schools, newspapers, and social, political, and charitable organisations. For the Dutch Catholics, over a third of the entire population around 1900, this subculture provided the context for their social emancipation and religious revival. In contrast to similar subcultures or milieus in Germany and Switzerland, the Catholic pillar in the Netherlands was very much led by clerics, who sternly directed the degree of rapprochement of their flock to what was summarised as modernity. ${ }^{18}$ This pillarisation provided ample training and battlegrounds for the secular and regular clergy, dressed in cassocks and habits, to demonstrate their authority and masculinity by their organisational and managerial skills far beyond the actual ecclesiastical domain. ${ }^{19}$

Once Catholic emancipation seemed to be complete with the settling of the long-lasting controversy over the state funding of confessional schools in 1917 and the advent of universal suffrage in 1919, the dominant role of the clergy in the Catholic milieu was openly called into question. Thus, in the Netherlands the end of the second age of confessionalisation in around 1930 went hand in hand with attempts by laymen to separate once again the ecclesiastical sphere from the professional, public, and political domains that had become entwined, pushing back the clergy to Church affairs, which were considered their proper business. This runs contrary to Olaf Blaschke's analysis in this volume, which puts the laity rather than the clergy in the centre of the transfer of religion from the Church's domain into the public, politi$\mathrm{cal}$, and professional spheres underway since the end of the nineteenth century.

With their authority challenged, the Dutch episcopate turned against what they defined as internal anticlericalism, embarrassing in the process the regular clerics like the Dominicans, who themselves had questioned the extent and impact of clerical control in an attempt to engage young Catholic intellectuals in new, modern forms of apostolate. In the Dutch province the debates over the extent and justification of clerical authority reached their peak in December 1932, when the young Dominican Raymund van Sante (1896-1946) was relieved of his duties on account of a booklet he had written entitled Gezag (Authority). Van Sante had pointed the finger at the moral and spiritual fragility of the clergy, encouraging well-educated lay Catholics to take the lead in the Catholic community and to support the clergy. This form of lay empowerment was condemned by the episcopate and by van Sante's own superiors, even though he had scrupulously based his argument on Thomas Aquinas, whose authority remained uncontested..$^{20}$

\footnotetext{
${ }^{18}$ Righart, De katholieke zuil in Europa, 29-36.

${ }^{19}$ Monteiro, “Mannen Gods”, 16-22.

${ }^{20}$ Monteiro, Gods Predikers, 203-211; Id., "Repertoires of Catholic Manliness".
} 
This affair caused young Dominicans like Grollenberg and de Winter to experience the full power of the order's existing structures of authority. In a series of retreats and conferences following van Sante's departure into exile in April 1933, decorum sacerdotale (priestly propriety) was drilled into these youngsters, in an unequivocal reassertion of the hierarchy of clergy and laity. At the same time, this decorum was intricately linked to what was called la virilité chrétienne. By demonstrating their dedication as religious, the Dominicans would not only embody the elevated nature of the religious state, but would also permit the laity to identify the characteristics of the priesthood more clearly. In 1935 one of the prominent Dominicans, the university professor Jan Benedict Kors (1885-1966), was keen to impress on an audience of younger fellow brothers the fact that: "A layman does not want a priest to be like a layman, but like a cleric, he does not want a priest to refrain from bad things, but wants to see that a priest behaves differently from a layman in what is permitted."21

His Flemish brother L.J. Callewaert (1886-1964) had in 1932 exhorted a similar audience to demonstrate their manliness in decorum sacerdotale by dutifully executing their tasks, and to be everything to everyone in the name of Christ, but equally to maintain a distance suitable for clerics in their contact with the laity. Being Godsmannen, 'men of God', demanded that "we avert our eyes from the people of this earth and turn them up high, to God". ${ }^{22}$

Propriety largely determined the career of each Dominican. In yearly reports on the condition of the province, the father provincial sent a catalogue of its individual members to the master of the order in Rome. ${ }^{23}$ It listed information on the entrance, profession, ordination, stations, and functions of each of the sons of the Dutch province. Moreover, it reveals how each father provincial in turn assessed the intellectual capacities, theological expertise, morality, and decency of their 'sons'. This assessment proved to be a reasonable forecast of the direction and career trajectory of each Preacher. Those who were endowed with a good mind, were theologically sound, and could boast of an impeccable record, were invariably chosen for administrative or academic responsibilities within the province or the order. Those who were judged to be intellectually or morally mediocre or somewhat fragile ended up in one of the parishes, whereas those with blatant moral or theological failings were considered a menace to the reputation of the order.

${ }^{21}$ PAOD 5868, Records of the Lacordaire debating club XVII, 242: Lecture by Jan Benedict Kors, OP, for the Lacordaire debating club of the young friars (2 May 1935), entitled Wij en onze tijd ('We and the present times'). See also PAOD 4589: Acts of the provincial chapter 1924, admonitio 6. A similar reasoning can be found in Stockums, Priesterschap en ascese, 288-289.

${ }_{22}^{2}$ PAOD 839: Notes of Bonaventura Jansen on the retreat by Callewaert, 6.

${ }^{23}$ Rome, Santa Sabina, Archives of the Generalate of the Order of the Dominicans, XIII, 77020: Catalogus omnium Fratrum Ordinis Praedicatorum Provinciae Reginae SS. Rosarii in Germania Inferiori. 


\section{GENERATIONAL DYNAMICS}

The majority of candidates for the order in fact wanted to become priests rather than monks. Interviews with Dominicans born between 1915 and 1940 clarify that it was often a mere coincidence that they had become a Preacher, and as such a 'priest religious'; they belonged to one of the parishes administered by Dominicans, or were related to a member of the order. All of them testify to a youth spent in an obviously Catholic culture, dominated by an active and intense practice of faith, anchored in parish life. Some of them practised being priests when they 'played Mass' (misje spelen) in their childhood. The privileged ones had been decked out for this purpose with decorated miniature cassocks and equally small replica altars. Between the ages of ten and twelve, most of these men had been selected as altar boys, assisting the priest, responding to his prayers, and ringing the little bell as the priest consecrated the Eucharist. Serving at Mass gave them a chance to experience - and enjoy - what it would be like to be a priest at the centre stage of a parish church. ${ }^{24}$

Contacts between parents and priests usually decided the selection of a minor seminary. The interviews illustrate that the standing and status of the Dominican order to a great extent determined its recruitment. Before the Second World War candidates were middle and upper middle class, often the sons of successful Catholic entrepreneurs who considered their entrance in the order befitting their social position. In the eyes of the young candidates, life as a Dominican mirrored the sophistication they had been used to since birth. "The liturgy, the culture, they [the Dominicans] were predikheren [gentlemen preachers], as they used to be called. I was used to that. At home everything was ... Well, we were well off, so everything was decent, sophisticated, and I recognised that way of life with the Dominicans."25

In the 1920 s the Dutch province witnessed a generational shift. According to Aleida Assmann, such shifts clarify how historical change affects both individual biographies and perceptions of history. Generations do not merely share a specific range of birth years, but also the experiences and patterns of interpretation that set them apart from other generations. Collectively shared processes to handle fundamental societal changes weld the members of a generation together, and determine by means of communication and discourse the parameters of their shared identity. ${ }^{26}$

The generation that died in the 1920 s was strongly associated with the heyday of Catholic emancipation. Amongst the grand old men who fostered a recognisable, self-reliant Catholic culture in the Netherlands were the Dominicans Vincentius de Groot (1848-1922), professor of Thomistic philosophy at the University of Amsterdam, Alfons Rijken (1859-1924) who had been a close friend and even the ghost writer of the Catholic social leader Alfons Ariëns (1860-1928), and Gerrit Meijer (1857-1925), the historian who had moulded the history of the Dutch Dominican Province into something of a success story. This generation was succeeded by younger Preachers whose lives and careers testified to their struggle against theological modernism between 1908 and 1914, as well as to their patriarchal clericalism. Their coping strategies,

\footnotetext{
${ }^{24}$ Interviews with Kees Strijbos, OP, 29 September and 4 October 2000.

${ }^{25}$ Interview with Alphons Voss, OP, 6 February 2001.

${ }^{26}$ Assmann, Geschichte im Gedächtnis, 32-36.
} 
which can be summarised as theologically cautious and socially self-glorifying, were subsequently resisted by the younger generation of intellectually trained Catholics. Although the Netherlands had been able to maintain its neutrality in the First World War, nonetheless its immense impact would be the deep-seated bond of the generations born between 1895 and 1910.

Dominicans who entered the order between 1915 and 1930 testified to differences of opinion with their older brothers over definitions of Catholicism as well as the role of the clergy in the Catholic milieu. Some of them discarded what increasingly was seen as a traditional and devotional Catholicism, rooted in an intense church-based practice of faith; they were inspired by new youth movements and student organisations that, in their opinion, reflected more decisive and effective forms of religious activism that they thought necessary for a revival of faith after the disillusionment caused by the First World War. For their part, the older brothers rejected this activism as anti-clerical, scorning the younger brothers for their energy, which they deplored as self-indulgent and anti-intellectual. The younger generation, in turn, complained about restrictions on their religious idealism, and questioned whether the spiritual needs of the times could indeed be met by the classical clerical repertoire of predications, which were centred on dogma and morality. If the Dominicans wanted to remain persuasive 'men of their times', they must recognise that this era called for different kind of men. Men of the new generation boasted that they were not stuck in any particular time, and were committed whatever the present times might demand. ${ }^{27}$

Van Sante was an extreme exponent of the views that welcomed attempts to strengthen the monastic dimension of Dominican identity. For the youngsters, it seemed to offer an escape from a lop-sided, clericalised Catholic culture that so incensed the more outspoken and critical members of their generation. The commemoration of the seventh centenary of the canonisation of St Dominic illustrates the search for a compromise between the generations, which turned on the proper balance of action and contemplation in Dominican life. Due to the acute controversy over clerical authority, which came to a head in the Dutch province in the van Sante affair, the centenary proved to be emotionally charged. Whereas in 1921, on the occasion of the seventh centenary of Dominic's death, members of the younger generation were invited to portray the founder of the order as they saw him, in 1934 only members of the established generation contributed to a commemorative volume. In 1921 the youngsters - of which van Sante was one - recast St Dominic as a heroic but mystically talented martyr for his faith whose moral rectitude and religious activism were founded in contemplation. ${ }^{28}$ In 1934 , their older brothers concentrated on the history of St Dominic's reception instead, carefully balancing his contemplativeness with apostolic action, and not mincing their words as to the clerical character of the foundation, highlighting both the self-assurance of its founder as well as his humble

${ }^{27}$ The records of the Lacordaire debating club of the young friars are particular testimony to this: PAOD 5865: Lecture by Rafaël Meussen, January 1928 (Verslagboek XV, 55-57); PAOD 5867: Lecture by Pius Kok, 8 March 1931 (Verslagboek XVII, 67-70).

${ }^{28}$ Feestuitgave van De Rozenkrans; De Rozenkrans, 43 (1921), 9-10. 
obedience to the Church hierarchy. ${ }^{29}$ At the same time, the contributions to the 1934 volume clearly continued the dual discourse of the reconciliation of clerical and monastic aspects of Dominican identity, yet overvaluing the monastic dimension by arguing that contemplation represented the true aim of the order in which the apostolate should be firmly grounded. They advocated an 'interactive' relation between action and contemplation, through which Preachers in their predication only shared with the faithful the things they had actively appropriated through contemplation. This approach influenced their interpretation of the order's motto, Contemplari et contemplata aliis tradere..$^{30}$

Whereas the authors of the 1934 volume agreed that the exact combination of contemplation and action highlighted the specificity of the Dominican's identity compared with the identities of diocesan priests or other priests religious, their discussion continued by considering the balance to be struck in this combination. This surely met with the approval of youngsters such as de Winter and Grollenberg, whose exchanges show that in their opinion they could effectively become men of their times without drawing any rigid distinctions between action and contemplation. De Winter, after all, questioned whether Dominicans in their daily lives were capable of distinguishing between the Dominican and the priestly ideals. He nevertheless remained aware of the implicit underappreciation of parochial work in his own province. When all was said and done, in their disquisitions on action and contemplation, and the so-called homogeneous activity in which both were harmonised, his learned brothers tended to equate action without saying with a professorship at one of the order's seminaries.

A professorship may be the most perfect form of homogeneous activity, but it is most certainly not the only one possible. Dominican Thomistic spirituality influences our predications as well as how we function as a confessors, ... in fact all our actions ... and turns them into instruction; then, too, our actions are toned with our contemplation. This is not a mere pretext for those who have not been called to a professorship, for they too are called to homogeneous activity. The more one thinks about this, the clearer it becomes that it is very, very useful, perhaps even necessary, that we influence the people by our actions in a Dominican manner. ${ }^{31}$

Like other members of his generation, de Winter recognised that some Catholics had distanced themselves from their Church and its clergy. He attributed this to the lopsidedly moral interpretation of faith, in which religion was equated with asceticism and the mere practice of virtue, humility, chastity, and mortification, instead of prioritising love fostered by contemplation. "What this actually means is that the

\footnotetext{
${ }^{29}$ Daniëls, OP, and Bruineman, OP, eds, Gedenkboek op het zevende eeuwfeest der heiligverklaring van St. Dominicus.

${ }^{30}$ Monteiro, Gods Predikers, 307-314.

${ }^{31}$ PAOD 8359a: Pius de Winter to Lucas Grollenberg, Nijmegen, 2 December 1943.
} 
attention to the transcendent life is concentrated on what is merely derivative of what is godly." ${ }^{2}$

Such ascetic approaches to faith - which de Winter mainly associated with the Jesuits - seemed to result only in a loss of faith. He illustrated his point by referring to the novel Het geschonden gelaat (The disfigured countenance), by a Roman Catholic convert, Dick Ouwendijk (b. 1907) that had just appeared in $1943 .{ }^{33}$ In 1953 Ouwendijk's oeuvre was hailed in an appreciation by L. J. Rogier, the prominent historian of Dutch Catholicism, as a model of the baroque, and inspired by French authors like Georges Bernanos and François Mauriac. Rogier ventured to guess that Ouwendijk's work was better received in Germany than in the Netherlands ${ }^{34}$, although this seems to be contradicted by the fact that the novel had already reached its fifth edition in 1947, a mere four years after its appearance. Rogier had reservations about the pessimism of Ouwendijk's work, with its recurring theme of a loss of faith because of legalistic interpretations of Christianity. Indeed, this sums up Het geschonden gelaat, which sets out to demystify Catholic family life and veneration for the clergy by describing the emotional disintegration of a family mirrored in the crumbling of the priestly calling of its eldest son. The son's unforgiving self-analysis was dismissed as "unchristianly dispirited and comfortless" by de Winter in his letter to Grollenberg in December 1943,

because Christian life is conceived merely as a battle ... against sin. Being Christian then means fighting evil and suffering on account of this battle; restlessness and discontentment are inherent to this outlook. ... God only enters the picture as a cause or a solution to these problems. Christ is nothing more than a hero of spiritual agony, a fearfully tormented human, without the peace of his Visio on his disfigured countenance. I truly fear that this will not help the mass of Christians to move beyond courageous resignation..$^{35}$

According to de Winter, contemplation could provide a more suitable answer to the questions with which his fellow Christians constantly wrestled, and without falling prey to the Weltschmerz Ouwendijk displayed in his book. These Christians lacked adequate guidance, and for that reason they were not aware of the peace and joy they were endowed with as tokens of the holiness of life. "Here lies a beautiful task for us [Dominicans] with our theo-logical training and our Thomistic spirituality, to take on Dominican instruction, in writing, from the pulpit, as confessors, by all our actions that is our 'homogenous' activity." ${ }^{36}$

${ }^{32}$ Ibid.

${ }^{33}$ Ouwendijk, Het geschonden gelaat.

${ }^{34}$ Rogier and de Rooy, In vrijheid herboren, 807.

${ }^{35}$ PAOD 8359a: Pius de Winter to Lucas Grollenberg, Nijmegen, 2 December 1943.

${ }^{36}$ Ibid. It. in original. 


\section{RESTORING ORDER}

Pius de Winter did not get a chance to practice what he had preached to Lucas Grollenberg. He was one of over 760 casualties of the accidental bombing of Nijmegen by Allied Forces on 22 February 1944. At half past twelve, just as he finished eating lunch with his brothers in the rectory of Maria's Nativity just outside the city centre, the air-raid alarm sounded. After about three-quarters of an hour the all clear sounded. De Winter helped wash up, and left for his rooms at the Dominican Sisters of the Most Sacred Sacrament in the lower town. Soon after, at a quarter past one, the city was bombed without warning. The teachers and pupils of St Dominic's heard an enormous explosion, which later turned out to be the tower of St Steven's Church collapsing. Immediately afterwards they saw disoriented people wandering the streets; some rang their doorbell, looking for help. The older pupils were drafted to clear the debris from the city centre, and were confronted with the full horrors of war from which their professors and superiors had tried to shield them. ${ }^{37}$

Since the outbreak of war in the Netherlands on 10 May 1940, the provincial Basil Schaab (1880-1956) had made every effort to ensure normality. He was responsible for nearly five hundred subordinates (subditi), including the pupils of St Dominic's, who needed to be fed, clothed, and housed once the Germans started to requisition the friaries in 1942. In spite of the ensuing diaspora, the business of the Dominican province went on much as usual if we are to believe the yearly chronicles that until 1945 listed deaths, funerals, appointments, exams, and ordinations. It was all as if there was no war on - and exactly as Schaab had hoped. In the midst of fear, insecurity about the future, and drastic upheavals such as those caused by the Germans' requisitions, he attempted to safeguard some continuity. He tried to do what most of the Dutch did during the German occupation: he carried on as normal. For the Dominicans, the monastic rhythm of the day provided a mental substrate for longedfor stability in turbulent times. It was only years after the Second World War that the Dominicans looked back with amazement on these years:

'Just do what you always did' seemed to be our loftiest ambition. That is why they [the superiors and teachers] withheld a great deal of information from us [the students and pupils]. The war was 'just' a passing thing. God and the Church and the vows and the scholarship with which we were acquainted were considered to be of lasting value. We were supposed to 'keep on doing what we always did' in order to become people of great worth after we had finished our education. And we did nothing but learn to argue in Latin ... as if the world depended on it. $^{38}$

The efforts to cling to routine as if nothing had changed also reflect the somewhat odd position of priests in society. In the Netherlands, diocesan priests and the ordained members of religious institutes were exempt from military service. Clerical 
and monastic varieties of Christian masculinity were generally cultivated without the battlefield as frame of reference. Army almoners were an exception to this rule, although they did not actually fight. ${ }^{39}$ However, the exemption from military service did not extend to the lay brothers at these institutes. During the Second World War, Dominican lay brothers were drafted as forced labour in the German war industry. This touches upon an intriguing paradox of masculinity in the Dominican community. Before the war every effort had been made to masculinise the way of life and duties of the lay brothers. Callewaert had explained in a brochure about the lay brothers ( $D e$ dominikaansche leekebroeder, published in 1931) that they cared for the Dominican fathers like mothers for their sons. Without infringing upon the internal hierarchy of ordination, he circumvented the pecking order by upgrading the work of lay brothers, and even spiritualising its impact with allusions to what Mary had done and had meant for Jesus. Callewaert voiced the general opinion that by running a friary's household effectively, the lay brothers enabled the ordained Preachers to engage in a fruitful apostolate. Nevertheless, the Dominicans periodically felt obliged to clarify the fact that the lay brothers' chores were manly, and called for sacrifices that should be viewed as heroic: "The art and diligence of the moment are also one of the characteristics of the manliness of the heroes. That manliness, that heroism has always been one of the features of the order of the Dominicans." 40 Yet when it came to their actual sufferings and heroism, however, there was a deafening silence when the enlisted lay brothers returned after the war. They were welcomed with a brief announcement to the effect that it was good to have them back as there was much work to be done.

This incident, which survives in the social memory of the Dutch province, illustrates both the immense variations in what its members experienced in the war, and the skimpy attention paid to those experiences afterwards. The Dominicans were not unusual in this ${ }^{41}$, but in their particular case it contributed to the image of unworldly Preachers who had only a slight idea of what was going in the world, and this was the image that stuck in the minds of young candidates for the order who received a letter from provincial Schaab when the war was over, ordering them to report to the noviciate in Huissen in July 1945. Arnold Diephuis (1926-2004) remembered the hardships he had to endure in order to get to Huissen from the west of the country where his parents lived, without valid travel documents in a country under military rule that closely monitored travellers, when there were still no trains running. He managed to get to Nijmegen, where the fathers of St Dominic's saw to it that he got to Huissen. There he too was welcomed as if nothing had happened; he was merely asked whether he still wished to become a novice. ${ }^{42}$

The privations are also illustrated by the preparations for Diephuis and the other members of his class to take the habit in September of 1945. There were no new habits available. They had to borrow habits from their brothers to be, which they wore for

${ }^{39}$ For example, the Dominican Ignatius de Boer (1895-1966), who was praised for his peace-loving heroism: PAOD, Personal file of Ignatius De Boer: Cutting from the Gelderlander, 16 April 1966; Lemeer, "Jan de Boer".

$4^{40}$ PAOD 8478: Retreat for the Brothers, 7 July to 3 August 1938.

${ }^{41}$ See for example Withuis, Na het kamp.

${ }^{42}$ Interview with Arnold Diephuis, OP, 11 April 2002. 
the few hours necessary for the ceremony before changing into civilian clothes again. After the Dominican missionaries stationed in the Dutch Antilles had come to their (financial) rescue, woollen fabric for new habits could be ordered from England. 43 Yet, instead of the usual two habits the novices had only one, so they still had to change into civvies once a fortnight when their habits were washed. And the habits they were given were old, threadbare, and heavily patched, "probably to teach us some humility", as Diephuis ventured to guess. ${ }^{44}$

Teaching humility to a generation that had been mentally and morally uprooted by the war proved to be a key feature in the mental renewal embarked on by provincial Laurentius Teeuwen (1898-1973), who succeeded Schaab in December 1945. In the 1920 s and 1930 s Teeuwen had been friends with van Sante, which raised suspicions as to his trustworthiness amongst the older brothers. After his election he accentuated the need to restore Dominican life according to the constitutions of the order devised by St Dominic himself. According to Teeuwen, prayer, worship of God, and a contemplative life dominated by silence and study provided meaning for the Dominican motto Contemplata aliis tradere. He stressed that renovatio, renewal, should be specifically geared towards the regeneration of spiritual life, which in turn would provide a fertile breeding ground for an active apostolate. ${ }^{45}$ Here Teeuwen's argument echoes familiar pre-war positions on action and contemplation. Yet the response from the general chapter of the order in 1946 reveals the political purport of this argument. It was convinced that Provincia Neerlandica est provincia optima. This positive evaluation, however, relied on everything but the parishes that were still the mainstay of the province. In fact, assessments of the province's financial situation established that the friaries, especially the philosphicum in Zwolle and the theologicum in Nijmegen, cost far more than they could ever bring in..$^{46}$

What the superiors in Rome valued in the Dutch Dominicans was their theological orthodoxy, their missionary work in the Dutch Antilles, Puerto Rico, and South Africa, and their attempts to recruit new candidates for the order. ${ }^{47}$ It was on the basis of these good points that the Dutch Dominicans attempted to restore their position as men of their times in the Dutch Catholic community, and to that end carefully blocked out the pre-war contention over clerical versus monastic identity, the dissension over authority in the Catholic community that had culminated in the van Sante affair, and even the Dutch Province's very nature as a 'parish province'. Instead, they tapped into the dual discourse of contemplation and action, bringing it to bear on a monastic and missionary masculinity that they in turn associated with St Dominic's founding ideals.

${ }^{43}$ PAOD 1855: Letter of the vicar provincial of the Dutch Antilles, Zeppenfeldt, to provincial Schaab, 10 September 1945.

44 Interview with Arnold Diephuis, OP, 11 april 2002.

45 Van Waesberge, “Ter nagedachtenis aan pater Laurentius Teeuwen o.p.”; see also PAOD 4679: Record of the morning session of the provincial chapter, 19 December 1945.

${ }_{46}$ Monteiro, Gods Predikers, 392-394.

${ }^{47}$ PAOD 4778: Letter of Methodius Hudeczek, assistant to the master of the order, Suárez, 19 January 1954. 


\section{ACCEPTED AND REJECTED LEGACIES}

The strategy of improving on a recent and complex past with a constructed and often simplified memory proved to be vulnerable, and had some way yet to go when in 1946 history caught up with the Preachers with news that van Sante had died in Cologne. His loyal supporters published an obituary in one of the major Catholic newspapers that raised the question in Rome of whether van Sante was still a member of the order; provincial Teeuwen confirmed that he was. In fact, the class of novices to which Arnold Diephuis belonged was required to say the office of the dead for van Sante, as was customary amongst the Preachers. Piet Struik (1926-2010), who was in the same class and would later be the provincial from 1981 to 1993 , remembers that he and his fellow novices were left completely in the dark as to van Sante's identity or the reason why he had died abroad. $4^{8}$ Their curiosity was further piqued during their studies, for in preparing a paper on the subject of authority one of them came across van Sante's booklet on authority, that had caused such a stir after its publication in 1932. In his paper the novice rebutted van Sante's views on authority as unorthodox, whereupon their director of studies, Andreas Maltha (1904-1994), lectured him for this hostile and, in his opinion, unjust evaluation of van Sante's position. Maltha leapt to the defence of his old friend, neglecting to mention that he himself had been posted to Rome in 1933 because of this friendship, and had not returned to the Dutch province until 1946, having both exonerated himself from the suspicion that he was not a trustworthy member of the order, and proved that he would abide by the official line on the question of lawful authority within the Church and the order. ${ }^{49}$ The whole affair thus reverberated amongst young Dominicans, no matter how much their older brothers tried to perform a damnatio memoriae on van Sante. It was not until the end of the 1950 s that one of the brothers ventured to utter van Sante's name once more, but by then he could dismiss the form of authority to which van Sante was forced to yield as totalitarian - an allusion which did not provoke any repercussions this time..$^{50}$

Besides such attempts to obliterate the unwanted legacies of the past, the Dominicans selected and appropriated other generally esteemed elements from the history of their order for a somewhat modernised self-presentation. In 1948 they published the small brochure, Wat is een Dominicaan? The initiator of this publication was Remigius Bruineman (1890-1970), the former prefect of St Dominic's, who had known Pius de Winter personally and had conducted his funeral. The father of de Winter's correspondent Lucas Grollenberg lent his professional support for the brochure's layout and publication, for he owned an advertising agency and was equipped to 'market' the Preachers and their apostolate through the modernised medium of the illustrated brochure. ${ }^{51}$ The ambitions of the pre-war brochures stretched no further than show-

\footnotetext{
$4^{8}$ Letter of Piet Struik, OP, to the author of this chapter, 28 August 2004.

${ }^{49}$ Monteiro, Gods Predikers, 515-519.

${ }^{50}$ It was Stephen Kreijkamp who mentioned van Sante in a lecture entitled 'Law and Conscience' given to the Nijmegen branch of the St Willibrord Vereniging, 21 February 1957 (Berg en Dal, Archive Sint Willebrord: Records of 18 October 1956 to 2 July 1959); see also my article "Clerical Authority and Prophetic Alternatives".

${ }^{51}$ PAOD 2849: Diary of Remigius Bruineman, 55 (1948), 94 (1951).
} 


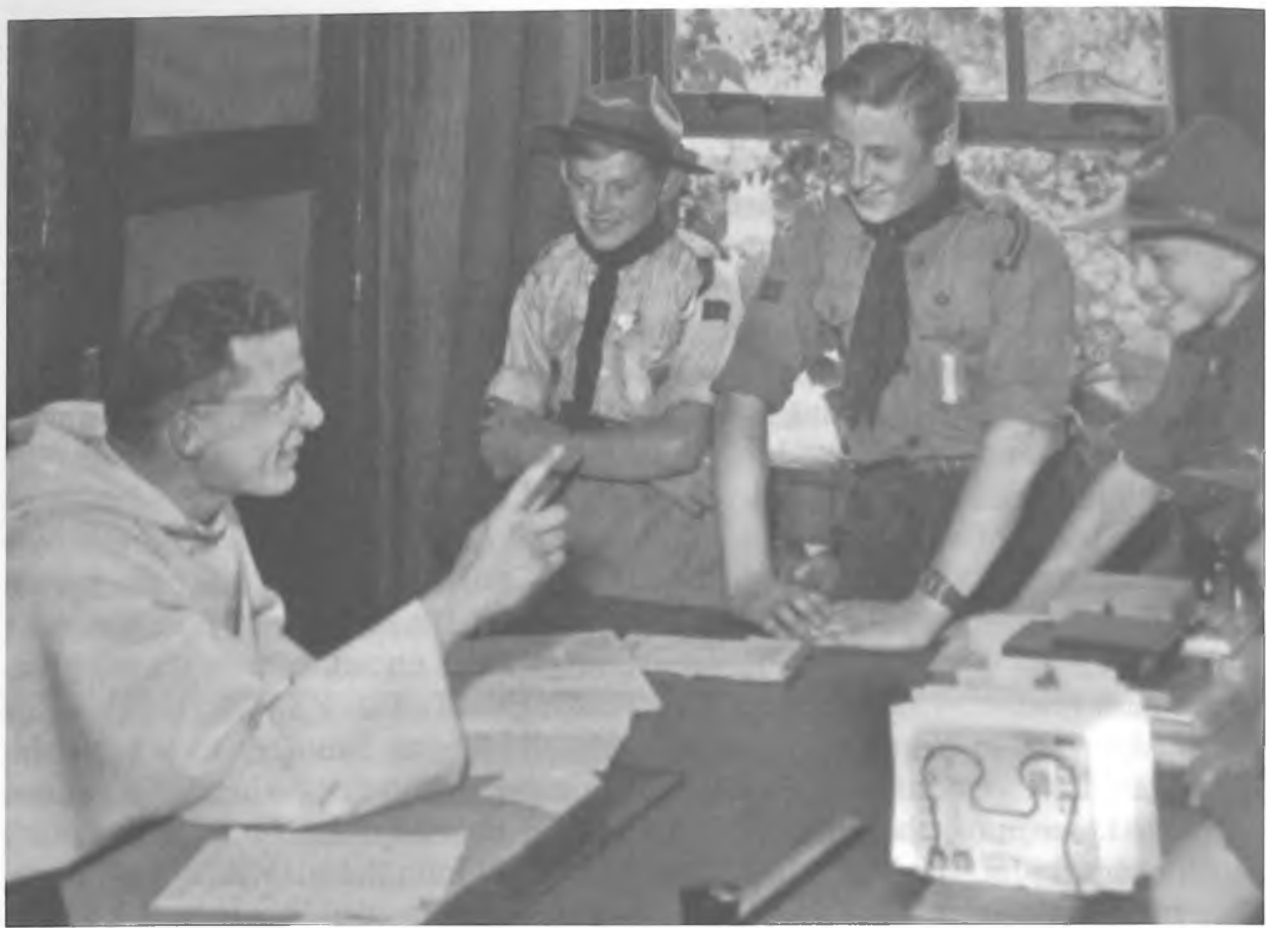

Conversation between a Dominican and pupils from the minor seminary.

[Picture taken from the brochure Wat is een Dominicaan, 1948]

ing the buildings of St Dominic's, with captions that lauded their modern comforts, leaving the question why young boys might want to become priests unanswered - it was supposed to be self-evident. In the brochure of 1948, the Dominicans themselves took centre stage, portrayed in action as missionaries, monks, preachers, and professors who devote their time to study and prayer. This combination was depicted as the fruitful basis of their missionary work at home and abroad. The effects of this apostolate are epitomised in three small pictures facing the first page. The first shows a Zulu who, according to the caption, has not remained unaffected by the majesty of Christ. It is the Dominicans, who have braved the dangers of the wilderness to bring the gospel to the heathens, as the second picture illustrates, who have revealed this dignity to him. In the third picture a group of people are sitting listening attentively to a Dominican preaching, as he towers over his audience in his white habit.

On the cover of the brochure a young Dominican is portrayed in the preaching attitude associated with Thomas Aquinas: right hand raised, index and middle finger held in the gesture of distinguo that befits the edifying Preacher. A group of young boys listens, apparently to the story that the leaflet tells from the perspective of a youngster. It begins in the present, not surprisingly at a missionary exhibition where

${ }^{52}$ Wat is een Dominicaan?, unpaged. 
the narrator meets a Dominican, but smoothly moves on to St Dominic's life and the missionary quality of his original ideal. St Dominic is portrayed as both intelligent and obedient to the Pope, who is said to voice the will of God. Grateful for their assistance, the Pope dubs the Dominicans the "true champions of faith", even at peril of their lives, as a list of the most memorable martyrs of the order illustrates. Christian masculinity of a Dominican nature is thus delineated along the lines of bravery, selfless martyrdom, and theological orthodoxy founded on the teachings of St Thomas. His books are equated to the rock on which heresy and unbelief have shattered for centuries, and account for the second epithet bestowed on the Dominicans, "lights of the world" - echoing Jesus's name for the apostles in the Gospel of St Matthew (5: 13-14). When it comes to the history of the Dutch Dominicans, the narrator dives deep into history to talk of the friaries founded during the Middle Ages; the Reformation, after which the Dutch Catholics and their secular and regular priests were forced to practice their faith in secret; and finally the foundation of the friary of Huissen in 1858 , where the assembled noviciate provided the seedbed for the future growth of the Dominican community in the Netherlands. This is followed by two pages filled with pictures that highlight the monasticism of several Dominican friaries, including one picture of a group of Dominicans during choral prayer. Only once is the word 'parish' mentioned: "Because the entire world is their parish." ${ }^{22}$

The trajectory for those who aspire to become Dominican is clearly laid out in the brochure, which goes on to address future candidates directly. It starts with the noviciate, where: "You learn to pray and meditate, where you will get to know your weaknesses that need remedy, and your strengths that ought to be further developed. In short: where you will learn to become a saint." ${ }^{53}$ After the first, temporary profession, the novice continues his training to become "a champion of faith and receiving the light of the world" at the friary of Zwolle.

For you are not just a religious. You are a Dominican. Every order has its own character. That of the order of the Dominicans is summarised in the character of St Dominic, expressed in two words: Champion - Light. Whereas you continue to mould the religious in yourself by choral prayer and meditation, you are taught in Zwolle and ... Nijmegen how to become a learned bantam-weight. ${ }^{54}$

This would take some six years, successfully rounded off by ordination. After that, the world would provide ample opportunity for missionary activity "in foreign countries, or as itinerant preachers in our own country" which offered all sorts of work, including "modern parochial work". The brochure ends as it began, with a picture of small boys in scout uniforms listening to a young Dominican who grasps their attention with his pointed index finger, although now on the back of the leaflet we see a somewhat larger group of boys than on the front cover, implying that the story has attracted more listeners.

The answer to the question 'What is a Dominican' was self-evident: a hero in the name of Christ, a man who feared nothing, who was willing to sacrifice everything in

${ }^{53}$ Ibid.

${ }^{54}$ Ibid. 
order to bring the faith to the entire world, which he could consider to be his parish. What was left unsaid was that over two-thirds of the Dutch Dominicans actually worked in parishes in the Netherlands and its dominions, and while the praises were sung of the missionary origins and character of the order, the brochure devotes little attention to the actual activities of the Preachers in their missions. In fact, the Dominicans did not consider them the preferred postings in the Dutch province because there they had to work in parishes that forced them to be men of the Church. Instead, the brochure moulded the Dominicans into monastic, militant and missionary men of God, excluding the historical development of the Dutch province as a province of parishes.

\section{CONCLUSION}

Religious institutions such as the order of the Dominicans do not have a collective memory; they create it. Conceptions of masculinity were central to the Erinnerungspraxis of the Dutch Dominicans. Until the 1920s they profiled themselves confidently as men of their times within the Dutch Catholic community, ever protective of the patriarchal structure of clerical authority. The re-monasticisation of Dominican identity, instigated at the international level of the order in the 1850s, was instrumentalised by the Dutch members to proclaim their superiority to the secular clergy. They were convinced that the monastic discipline to which they were subjected better qualified them for an effective apostolate. By separating their identity as Dominicans from their function as parish priests, they were able to reconcile the monastic and clerical aspects of their identity.

By the 1920 , however, their position as priests religious working in parochial pastorates became particularly problematic. Internationally, they were the odd ones out in their own order, which considered parochial responsibilities a necessary evil rather than a proper Dominican concern, and proved increasingly ignorant of the parochial duties of the majority of its Dutch brethren. In the Netherlands, the Dominicans were confronted by the anticlericalism of young, educated Catholic men, who defied the patriarchal power of the priesthood with their vital and virile forms of Catholic engagement. The representatives of older generations now in charge of the Dutch province stuck with the familiar patriarchal repertoire of clerical authority, while emphasising the monastic dimensions of Dominican identity as a healthy check on the busy parish life that most of them led. Younger brothers had greater difficulties reconciling homo Dei with homo Ecclesiae. For some, like van Sante, there was an unbridgeable gulf between them. In his opinion, men of the Church represented the complacent Catholicism of bourgeois culture, to be contrasted with the authentic evangelical zeal displayed by men of God. ${ }^{55}$ Others, like de Winter and Grollenberg, did not consider the distinction between homo Dei and homo Ecclesiae to be irreconcilable. Their views were echoed in the brochure of 1948 that explained what a Dominican was to potential recruits.

${ }^{55}$ For the tendency to contrast clerical masculinity with what was considered to be bourgeois manliness, see Yvonne Maria Werner's chapter in this volume. 